J. Product. \& Dev., 24(4): $807-814$ (2019)

\title{
EFFICACY OF SOME WINTERING METHODS ON THE ACTIVITY OF HONEYBEE COLONIES (Apis mellifera L.)
}

\author{
Samia I. A. El-Sayyad ${ }^{1} ;$ H. E. El-Sharkawy ${ }^{2}$ F. El-Santeel ${ }^{2}$ and \\ Sanad, R. E. ${ }^{1}$ \\ 1. Plant Protection Research Institute, A.R.C., Dokki, Giza-Egypt. \\ 2. Department of Plant Production, Faculty of Technology \&Development, \\ Zagazig University, Egypt \\ m_khattaby9111@yahoo.com,hamzash@hotmail.com,walaareda52@yahoo.com
}

\begin{abstract}
This work was carried out to study the efficacy of thermal insulation methods during fall on brood rearing activity of F1 Carniolan and F1 Italian hybrid colonies. The experiments were conducted at a private apiary in Hehia district, Sharkia Governorate, Egypt.

Results showed that the highest measured total sealed brood area was recorded for the thermo-insulated colonies with foam for F1 Carniolan and F1 Italian both hybrids colonies, recording 1334.8 and 1441.4 inch $^{2} /$ colony, respectively. On the contrary, control colonies received no insulation measure reared the least total sealed brood area, recording 998.8 and 1074.2 inch $^{2} /$ colony brood rearing activity of the two hybrids was the highest starting on November $1^{\text {st }}$ regardless of the insulation material. Thereafter this activity suffered gradual decrease till mid winter before it started to increase again.

Italian hybrid colonies showed higher brood rearing activity during fall more than Carniolan hybrid colonies.

Conclusively, from previous results, thermal insulation by foam is the best type of thermal insulation for bee sects under study.

Key words: Honeybee, thermal insulation, canvas, foam, sealed brood area, stored pollen area
\end{abstract}

\section{INTRODUCTION}

Honeybee is considered the most important economic insect, because of its important role in pollinating field and horticultural crops, bee products and for export. In addition, honeybee projects offer (provide) job for nonemployer youth and in rural communities.

Like other insects, honeybee colonies are affected by the climatic factors, leading to loss of bee colonies due to low temperatures, although 
bees can adapt at low temperatures up to $-4^{\circ} \mathrm{C}$ (Szabo 1985), but brood nest need $32^{\circ}-36^{\circ} \mathrm{C}$ for development (Seeley and Heinrich 1981; Southwick and Heldmaier 1987). Moreover, the low temperature below $10^{\circ} \mathrm{C}$ can prevent flight activity (Joshi and Joshi 2010), the colonies in cold climates attend to have a lot of adult bee more than the colonies in warmer places in Northern Europe (Hatjina et. al., 2014) . Therefore, beekeepers resort to reduce the loss of colonies of bees by requlating temperatures inside the colonies using different methods during winter season. Some resorted to heat insulation using nylon (El-Jassani and Alkinani, 2010) or foam (El-Shikh, 2007 and Abd-Elmawgood, et al. 2015). Wineman et al. (2003) warming the honeybee hive with solar heaters by placing the colonies inside Infrared-Polyethylene covered enclosures, while others have used hives with several dimensions and size (Abd-Elmawgood et al. 2015). Satta and Floris (2004) found that the hives which made from cork and fir wood were more regular in temperature control than those made of fir wood only, where the former reduced the consumption honey stores during winter by approximately $36 \%$. Moreover, Taha (2014) used foam hives to increase the sealed brood area and stored pollen inside the hives to by the wooden hives. Omran (2011) used electric power for increase hive temperature by $72.48-84.27 \%$ that increased (sealed brood, pollen, honey) area and bee population.

Therefore, the present work was carried out to find out the most suitable coverage for bees for inducing brood rearing activity.

\section{MATERIALS AND METHODS}

The present work was carried out in a private apiary located in Hehia district, Sharkia Governorate, Egypt during fall season from the first of November 2018 to the first of March 2019 to evaluate the efficacy of two types of thermal insulating thermals on brood rearing activity of F1 Carniolan and F1 Italian honeybee hybrid colonies.

\section{1- Materials :}

a- Thermomerters:

A total of 5 Celisus thermometers was used for measuring temperature inside the hives within brood nest. The thermometers act by liquid ether. Each thermometer is of $30 \mathrm{~cm}$ length and $5 \mathrm{~mm}$ diameter.

\section{b- Insulating materials:}

- Foam : Foam sheets of a thermal conductivity $\left(0.038 \mathrm{Ww}^{-1} \mathrm{~K}^{-1}\right)$ and $1 \mathrm{~cm}$ thickness were used as a thermal insulator. 
- Canvas: Pieces of jute texture of a suitable area to allow complete coverage of the hive box.

\section{2- Experimental colonies:}

Thirty nuclei were initiated from strong colonies, nearly of the same strength as possible (6 combs covered by bees, sealed brood, stored pollen and honey), that were divided into two groups of 15 colonies each. Colonies of the first group was headed by F1 Carniolan mated queens while the second group was headed by F1 Italian mated queens.

Each group was divided into 3 subgroups of 5 colonies each as follow:

- The first subgroup colonies were insulated by foam.

- The second subgroup colonies were insulated by canvas.

- The 3rd subgroup colonies were without insulating cover (control).

The tested colonies were fed on sucrose syrup ( 2 sugar : 1 water) as well as a pollen substitute as usual.

\section{3-Measuring sealed brood:}

Worker sealed brood area was measured at 12 day intervals (Fresnay, 1962). Measuring process was performed around mid-day to minimize bee string. Bees covering each brood comb were firstly shaken off, then sealed brood area was measured on both sides of brood comb using transparent rigid plastic sheets divided into square inches.

\section{4-Measuring brood nest temperature:}

Air temperature in brood nest of each colony was measured 5 times in each day of inspection (8a.m., 10 a.m., 12 noon, 2p.m. and 4 p.m.), using 100 $\mathrm{C}^{\mathrm{o}}$ thermometer, that inserted between brood combs through a hole made in the back wall of all the test hives. The correlation coefficient values (r) between brood nest temperature and sealed brood area was calculated according to Snedecor and Cochran (1967) methods.

\section{5-Statistical analysis:}

Data obtained were statically analysed according to Snedecor and Cochran (1982) using Computer Program Anonymous (2005).

\section{RESULTS AND DISSCUTION}

\section{Worker sealed brood area:}

Data in Table (1) clear worker sealed brood area inch ${ }^{2} /$ colony of F1 Carniolan and F1 Italian hybrids colonies during fall as affected by the insulation methods. 
Data reveled that brood rearing activity during fall was started in higher rates (on Sept. $1^{\text {st }}$ ), in all treatments then it decreased gradually until recording the lowest values on Jan. 24 for Carniolan hybrid and on February 17 for Italian hybrid. Thereafter a gradual increase in this activity was then taken place.

Obtained results clear that the total sealed brood area measured in F1 Carniolan hybrid colonies attained 133.43, 1212.2 and $998.8 \mathrm{inch}^{2} /$ colony for the colonies covered with foam and canvas, as well as, control colonies (without coverage), respectively. The corresponding figures for F1 Italian hybrid colonies were 1441.0, 1229.8 and $1074.7 \mathrm{inch}^{2} /$ colony (Table, 1). It is obvious that F1 Italian hybrid colonies reared more brood during fall as compared to F1 Carniolan hybrid colonies. This finding seemed to be genetic one, as Italian queens are more prolific than Carniolan ones. This statement is in accordance with that of (Khattaby, 2018).

Regarding the impact of the insulating material, it is clear that foam, as insulating material proved to be the best, as foam covered colonies reared the highest sealed brood area on all dates of inspection, recording between 91.0153.6 and 95.6-177.6 inch ${ }^{2} /$ colony for F1 Carniolan and F1 Italian hybrids colonies, respectively. Moreover, correlation coefficient values between inside-hive temperature and sealed brood areas measured in the foam insulated hives were mostly significant.

Canvas came in the second class, recording between 89.2-133.0 and 82.8-159.6 inch $^{2}$ sealed brood area/colony. On the other hand, control colonies (without any coverage) reared the least sealed brood area, that ranged 77.4-117.6 inch $^{2} /$ colony for F1 Carniolan hybrid colonies, and between 71.2-136.2 $\mathrm{inch}^{2} /$ colony for F1 Italian hybrid colonies. Doubtless, the higher brood area in the colony caused higher population which generate heat energy to thermo-regulate (optimize) the brood nest temperature around

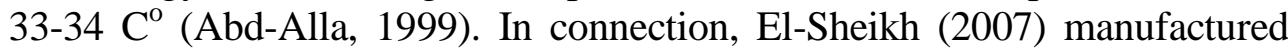
modified Langstrowth hives insulated with foam sheets inserted between the double wooden sheets wall to help bee colony to regulate inside hive. 
temperature as a safety measure to rear healthy brood. He gained promising results in this respect. Taha (2014) and Abd-Elmawgood et. al. (2015) results supported these findings.

According to the results of the present work, beekeepers are advisable to help their colonies in thermo-regulating process by feeding the bees when necessary to avoid starvation and bee losses during cold periods, to control bee diseases which reduce bees immunity and to use insulating coverage to prevent heat dispersal.

Conclusively, from previous results, thermal insulation by foam is the best type of thermal insulation for bee sects under study.

\section{REFERENCES}

Abd-Alla, M. A.(1999) : Biological and ecological studies on honeybee (Apis mellifera L.). M. Sc. Thesis, Fac. Agric. Zagazig Univ., Egypt.

Abd-Elmawgood, B. H.; Al-Rajhi, M. A. and El-Ashhab, A. O. (2015): Effect of the internal size and thermal insulation of the hive on bee colonies strength and productivity. Egypt. J. Agric. Res., 93(1):185-196.

Anonymous (2005) : COSTAT Computer Program Version 6.311, Copyright (C) , Coltart Software 798 Lighthouse Ave. PMB 320,Monterey, CA, 93940 , USA.

El-Jassani, R. F. and Alkinani, M. A. (2010): Effect of over wintering types on the activity of the honey bee and the infection by the fungi. Anbar $J$. of Agric. Sci., ISSN: 19927479, (8),: 258-262

El-Shikh, F. M. E. (2007): Engineering studies on honeybee hives. M. Sc. Fac. Agric. Zagazig University, Zagazig, Egypt.

Fresany, J. (1962): A new instrument for brood measurement in honey bee colony. Am. Bee J., 111(1),: 20-21.

Joshi N. C. and Joshi P. C. (2010) : Foraging behaviour of Apis spp. on apple flowers in a subtropical environment. NY Sci. J., 3: 71-76.

Hatjina, F.; Costa, C.; Buchler, R.; Uzunov, A.; Drazic, M.; Filipi, J.; Charistos, L.; Ruottinen, L.; Andonov, S.; Meixner, M. D.; Bienkowska, M.; Dariusz, G.; Panasiuk, B.; Conte, Y. le; Wilde, J.; Berg, S.; Bouga, M.; Dyrba, W.; Kiprijanovska, H.; Korpela, S.;Kryger, P.; Lodesani, M.; Pechhacker, H.; Petrov, P., and Kezic, N. (2014): Population dynamics of European honey bee genotypes under different environmental conditions. (Special Issue: Genotype environment interactions). Journal of Apicultural Research: 53(2):233-247. 
Khattaby, M. A. (2018): studies on some factors affecting acceptance and mating success of honeybee queens. M. Sc., Fac. Agric. Zagazig University, Zagazig, Egypt.

Morse, R. (1999): Wintering basics for northern beekeepers. Bee Culture, 127: 24-26.

Omran, N. S. M. (2011): wintering of honeybee colonies (Apis mellifera L.) by using a new technique during winter season in Sohag region, Egypt. J. of Applied Sciences Research, 7(2): 174-182, 2011.

Satta, A. and Floris, I. (2004): Effects of the cork on the thermal insulation and the thermoregulation of bee hive. Agris J. 37, (6) : 305-309

Seeley, T. and Heinrich, B. (1981): Regulation of temperature in the nests of social insects. Pages 159-234 in B. Heinrich, ed. Insect Thermoregulation, John Wiley \& Sons, New York.

Snedecor, G.W. and Cochran, W.G. (1982). Statistical Methods Applied To Experiments In Agricultural And Biology. The Iowa State College $5^{\text {th }}$ ed., Iowa, U.S.A.

Southwick E. E. and Heldmaier G. (1987): Temperature control in honey bee colonies source: Bio Science, American Institute of Biological Sciences. 37, (6), : 395-399

Szabo, I. T. 1985: The thermology of wintering honey bee colonies in 4coloy packs as affected by various hive entrances. J. Apic. Res., 24 (1) : 27-37.

Taha, A. A. (2014): Effect of hive type on strength and activity rate of honeybee colonies (Apis mellifera L.) in Egypt. J. Plant Pro. and Path., Mansoura Univ., 5(6): 773-784, 2014.

Wineman, E.; Lenski Y. and Mahrer Y. (2003): Solar heating of honeybee colonies (Apis mellifera L.) during the subtropical winter and its impact on hive temperature. Worker population and honey production. Am. Bee J., 143: 565-570. 
كفاءة بعض طرق التثنية على انشطة طوائف نحل العل Apis) mellifera L.)

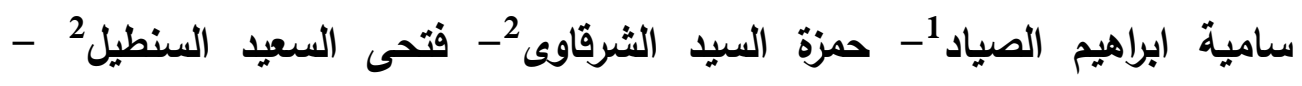
رضا عليوه سند 1

1 - معهز بحوث وقاية النباتات - قسم بحوث النحل - الجيزة

2 - قسم الاتتاج النباتى - كلية التكنولوجيا والتنمية - جامعة الزقازيق

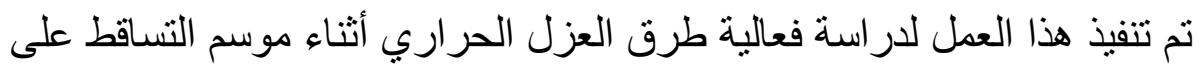

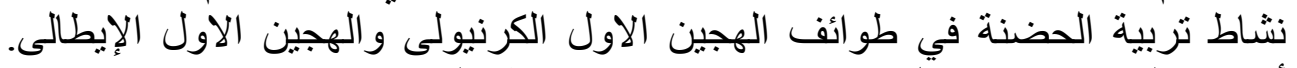

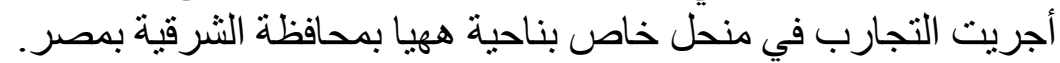

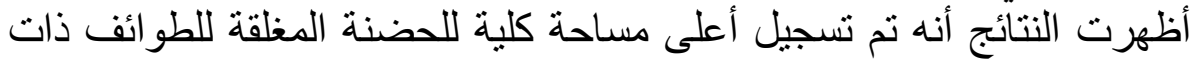

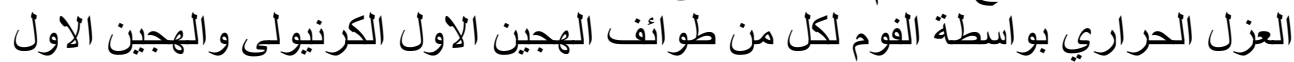

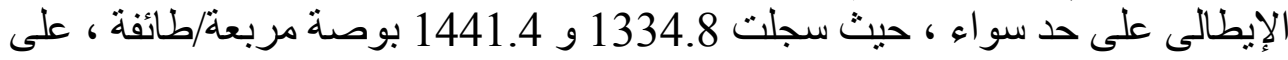

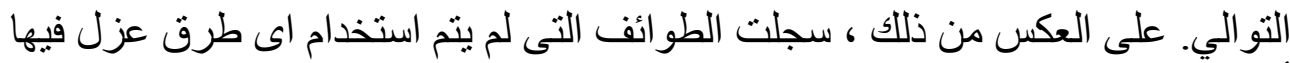

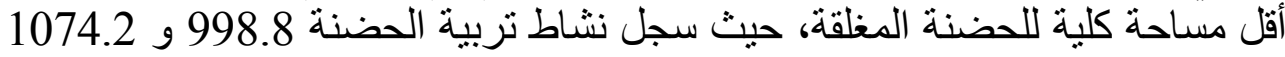
بوصة مربعة/طائفة للهجينين على الترتيب.

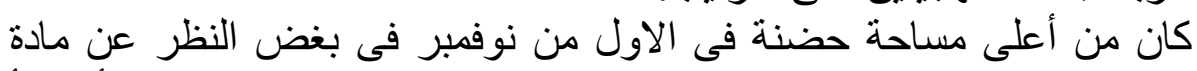

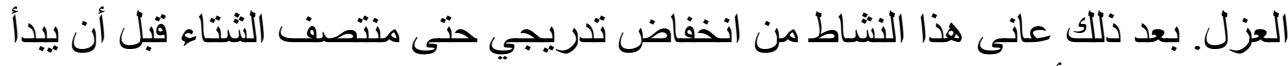

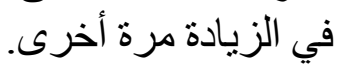
أظهرت الطوائف للهجين الاول الايطالى نثاط تربية حضنة أعلى خلال الدراسة

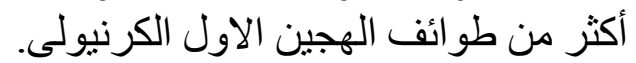
التوصية: من النتائج السابقة ان العزل العزل الحرلى الحرارى بواسطة الفوم افضل انواع العزل الحر ارى لطو ائف النحل تحت الدراسة النة. 